DOI: https://doi.org/10.47405/mjssh.v6i11.1152

\begin{tabular}{|c|c|}
\hline 4 & Malaysian Journal of Social Sciences and Humanities (MJSSH) \\
\hline $\begin{array}{l}\text { Malaysian Juoural of } \\
\text { Social ccciecces and }\end{array}$ & Volume 6, Issue 11, November 2021 \\
\hline (MJ-sSH) & e-ISSN : 2504-8562 \\
\hline & $\begin{array}{l}\text { Journal home page: } \\
\text { www.msocialsciences.com }\end{array}$ \\
\hline
\end{tabular}

\title{
Cabaran Terhadap Pihak Perkhidmatan Kurier dan Pengguna Semasa Pandemik Covid-19
}

\author{
Nor Farahin Md Danial ${ }^{1}$, Nor Fatihah Md Afif ${ }^{1}$, Mohamad Izzuan Mohd Ishar ${ }^{1}$ \\ 1Sekolah Pendidikan, Fakulti Sains Sosial dan Kemanusiaan, \\ Universiti Teknologi Malaysia (UTM), Malaysia
}

Correspondence: Nor Fatihah Md Afif (fatihafif97@gmail.com)

\begin{abstract}
Abstrak
Kajian ini bertujuan untuk mengetengahkan dan menyelidik cabaran yang dihadapi oleh pihak perkhidmatan kurier dan pengguna akibat daripada peningkatan penggunaan perkhidmatan kurier dalam kalangan masyarakat semenjak Pandemik Covid-19 yang melanda Malaysia. Satu tinjauan dalam talian digunakan untuk mengumpul data. Terdapat 50 responden dalam kajian ini yang terdiri daripada 20 lelaki dan 30 wanita. Antara syarikat perkhidmatan kurier yang terdapat dalam kutipan data adalah Pos Malaysia dan J\&T Express. Pengutipan data dilakukan kepada responden dalam anggaran umur yang berbeza dengan menilai perkhidmatan kurier pilihan pengguna, faktor kecenderungan membeli secara atas talian, kuantiti barangan yang dipesan, kepuasan terhadap perkhidmatan kurier. Keputusan daripada kajian tersebut didapati terdapat beberapa cabaran penggunaan perkhidmatan kurier yang dihadapi oleh pengguna sekaligus memberikan impak kepada pihak perkhidmatan kurier tersebut.
\end{abstract}

Kata kunci: Covid-19, perkhidmatan kurier, pengguna

\section{The Challenges to the Courier Services and Consumer During the Covid-19 Pandemic}

\begin{abstract}
This study aims to highlight and investigate the challenges faced by courier services and consumers as a result of the increasing use of courier services among the community since the Covid-19 Pandemic that hit Malaysia. An online survey is used to collect data. There were 50 respondents in this research consisting 20 of men and 30 women. Among the courier service companies available in the data collection are Pos Malaysia and J\&T Express. Data collection was carried out to respondents in different age estimates by evaluating the consumer choice of courier service, factors of the tendency to buy online, the number of goods ordered, satisfaction with courier service. The results of the study found that there are several challenges when using the courier services that are faced by consumers as well as giving an impact to the courier services also.
\end{abstract}

Keywords: Covid-19, courier services, consumer 


\section{Pengenalan}

Covid-19 pada mulanya muncul di negara Wuhan, China pada Disember 2019 sehingga melanda seluruh dunia dan telah menyebabkan terjadinya penyakit berjangkit. Covid-19 merupakan satu wabak tergempar yang menyerang kesihatan manusia sehingga boleh membawa kepada kematian. Malaysia juga terkesan dengan kehadiran wabak Covid-19 ini. Walaupun sudah lebih daripada setahun wabak ini melanda dunia namun kadar positif dan kematian juga masih meningkat dari hari ke hari. Akibat daripada peningkatan demi peningkatan kadar positif di Malaysia, pihak kerajaan telah memutuskan untuk melaksanakan Perintah Kawalan Pergerakan (PKP) di seluruh Malaysia. Dengan terlaksananya PKP, masyarakat tidak bebas berbelanja di luar dan masyarakat telah mengambil inisiatif untuk menggunakan perkhidmatan kurier sebagai perantaraan pembelian keperluan dan kehendak masyarakat. Perkhidmatan kurier merupakan satu sistem pengeposan yang ditubuhkan oleh syarikatsyarikat kurier bagi membantu penghantaran pesanan surat atau barangan oleh pengguna. Perkhidmatan kurier ini telah menjadi salah satu jalan pengguna untuk menyampaikan surat atau barangan kepada seseorang. Antara syarikat perkhidmatan kurier yang telah terkenal di Malaysia adalah Pos Laju, J\&T Express, City Link Express dan terdapat juga beberapa syarikat perkhidmatan kurier yang masih baru seperti Ninja Van. Perkhidmatan ini sering digunakan oleh pengguna untuk memesan surat atau barangan kepada orang yang berada jauh dari tempat tinggal mereka.

Pertumbuhan penjualan secara atas talian telah menjadi tumpuan antara pihak peniaga dan pembeli untuk menggunakan perkhidmatan kurier semenjak wabak Covid-19 ini melanda. Hampir kesemua jenis barangan dibeli secara atas talian oleh pengguna seperti barangan elektrik, pakaian dan tidak ketinggalan juga makanan kering yang tahan lama. Perlaksanaan PKP yang di jalankan oleh pihak kerajaan ini telah memberi lonjakkan kepada penggunaan perkhidmatan kurier di kalangan masyarakat Malaysia. Hal ini telah menyebabkan, perkhidmatan kurier berkembang dan mendapat permintaan yang meningkat secara mendadak. Sebelum ini, perkhidmatan kurier dianggap satu perkhidmatan yang biasa dan tidak begitu diperlukan oleh masyarakat tetapi sejak munculnya wabak Covid-19 yang melanda dunia, perkhidmatan ini sangat diperlukan dan merupakan satu perkhidmatan yang digunakan oleh hampir kesemua masyarakat kini. Hal ini kerana, wabak Covid-19 yang sentiasa meningkat hari demi hari telah menyebabkan kerajaan menyarankan masyarakat untuk tinggal di rumah jika tiada urusan yang penting bagi mencegah jangkitan wabak tersebut serta memberhentikan penyebaran rantaian wabak Covid-19 ini.

Peningkatan penggunaan perkhidmatan kurier sepanjang pelandaan Covid-19 ini telah menimbulkan beberapa isu terhadap perkhidmatan kurier di negara Malaysia. Walau bagaimanapun, pihak perkhidmatan kurier tetap berusaha untuk memberikan perkhidmatan yang terbaik kepada pengguna. Peningkatan permintaan oleh pengguna itu menyebabkan pihak perkhidmatan kurier perlu menempuh pelbagai cabaran seperti lambakan bungkusan yang perlu dihantar dalam kadar tempoh yang telah ditetapkan bagi mengekalkan pemberian perkhidmatan yang terbaik. Tidak hanya itu, pengguna juga terlibat dalam menempuh beberapa cabaran seperti kerosakan atau kehilangan barangan yang dikirim serta penerimaan bungkusan dalam tempoh yang lebih lama berbanding sebelum wabak Covid-19 melanda. Perkara ini sedikit sebanyak telah memberi tekanan pada pihak perkhidmatan kurier dan juga pengguna. Oleh itu, cabaran-cabaran yang melanda perkhidmatan kurier dan pengguna perlulah dilalui dengan bijak agar dapat menempuh cabaran ini sehingga selesai dalam keadaan yang baik.

\section{Objektif}

Tujuan kajian terhadap pihak perkhidmatan kurier dan pelanggan semasa pandemik Covid-19 ialah:

i. Untuk mengetahui peningkatan penggunaan perkhidmatan kurier semasa pandemik Covid- 19.

ii. Untuk mengenal pasti cabaran terhadap pihak perkhidmatan kurier dan pengguna semasa pandemik Covid-19. 


\section{Kajian Literatur}

Kajian literatur ini dilakukan sebagai rujukan kepada pengkaji dalam menjalankan kajian ini. Dalam bab ini pengkaji mengetengahkan penyelidikan terdahulu yang berkaitan dengan objektif kajian ini. Kajian literatur yang diperoleh dari sumber-sumber yang asli daripada pengkaji dan penyelidik lain serta maklumat-maklumat terkini di internet membantu menyokong dan mengukuhkan isu-isu yang dikaji.

Peningkatan penggunaan perkhidmatan kurier adalah berpunca daripada sesuatu faktor yang mempengaruhi peningkatan tersebut. Reginald dan Michael (2020), menyatakan bahawa wabak Covid-19 telah menjadikan permintaan semakin meningkat dalam pengeposan makanan dan barangan keperluan. Dengan lebih jelas, menurut Reginald dan Michael (2020), permintaan perkhidmatan kurier telah meningkat sejak bermula wabak Covid-19 kerana masyarakat beralih daripada pembelian secara bersemuka ke pembelian secara atas talian kerana keperluan masyarakat untuk kuarantin di tempat tinggal mereka. Kenyataan ini hampir sama dengan kenyataan daripada Ketua Pegawai Eksekutif Pos Malaysia, Syed Md Najib Syed Md Noor (2020), bahawa segmen kiriman bungkusan mendapat permintaan tinggi, disokong dengan lonjakkan pembelian dalam talian oleh rakyat Malaysia pada ketika arahan kerajaan supaya rakyat kekal di rumah.

Oleh sebab itu, kajian peningkatan penggunaan perkhidmatan kurier dapat membantu penyelidik untuk mengetahui faktor peningkatan penggunaan perkhidmatan kurier. Ianya juga menggambarkan cabaran yang dihadapi oleh pihak perkhidmatan kurier dan pengguna sepanjang peningkatan penggunaan perkhidmatan tersebut. Menurut Caren (2020), cabaran yang dilalui oleh pihak perkhidmatan kurier dan pengguna adalah lambakan barangan di pusat perkhidmatan kurier yang akan menyebabkan kelewatan penghantaran barangan yang akan menimbulkan rasa tidak puas hati pengguna kepada perkhidmatan kurier tersebut. Lambakan barangan bukan sahaja memberi kelewatan penghantaran tetapi juga berlaku kerosakan pada barangan yang dikirim.

Hal ini memberi sedikit sebanyak kesan kepada pihak perkhidmatan kurier kerana ketidakpuasan hati pengguna yang menyebabkan pengguna beralih kepada syarikat perkhidmatan kurier yang lain. Oleh itu, kajian ini adalah salah satu cara untuk meneroka cabaran-cabaran yang dilalui oleh pihak perkhidmatan kurier dan pengguna semenjak wabak Covid-19 melanda. Penyelidikan dilakukan ke atas pengguna dapat dijadikan maklum balas mengenai keadaan isu antara pihak perkhidmatan kurier dan pengguna. Seterusnya, penambahbaikan pihak perkhidmatan kurier dapat dilakukan pada masa hadapan melalui maklum balas yang diberikan oleh pengguna terhadap perkhidmatan mereka.

\section{Metod Kajian}

Kajian ini merupakan satu kajian deskriptif. Kajian ini menggunakan reka bentuk kajian kuantitatif dan borang soal selidik sebagai instrumen. Sasaran responden kajian ini ialah pengguna yang menggunakan perkhidmatan pengeposan oleh Pos Malaysia. Maklumat tersebut kemudian dianalisis untuk menjawab persoalan kajian ini. Borang soal selidik diedarkan secara atas talian iaitu seramai 50 orang responden, borang soal selidik ini mengandungi hanya satu bahagian terhadap cabaran oleh pihak perkhidmatan kurier dan pengguna yang membeli barangan secara atas talian. Borang soal selidik ini menggunakan pilihan jawapan "Ya" atau "Tidak" untuk setiap persoalan yang diajukan kepada pengguna.

\section{Hasil Kajian}

\section{Analisis Demografi kajian}

Bagi menceritakan latar belakang responden, maklumat balas dari responden adalah penting kerana maklumat tersebut menceritakan mengenai latar belakang responden untuk kajian. Latar belakang 
responden yang berbeza dapat memberikan pandangan yang menarik terhadap isu yang akan menjadi perbincangan. Antara maklumat responden yang dikaji dalam kajian ini adalah umur dan jantina pengguna dalam pengeposan barang terhadap barangan yang dibeli atas talian.

Carta 1 menunjukkan jumlah peratusan responden dalam soal selidik kajian ini. Responden dalam kajian ini terdiri daripada 20 orang lelaki dan 30 orang perempuan. Jumlah keseluruhan adalah seramai 50 orang pengguna yang menggunakan perkhidmatan pengeposan daripada Pos Malaysia. Seramai $60 \%$ adalah responden perempuan, manakala selebihnya $40 \%$ adalah merupakan responden lelaki. Carta ini menunjukkan terdapat peratusan responden perempuan lebih ramai berbanding denagan responden lelaki.

Carta 1: Jantina

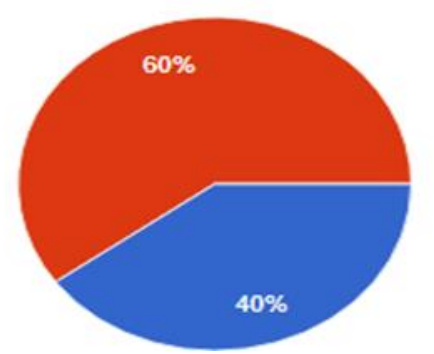

Lelaki

Perempuan

Carta 2 ini menunjukkan perbezaan umur responden. Dalam kajian ini, terdapat tiga perbezaan umur pengguna iaitu 18-25 tahun, 26-35 tahun dan 36-46 tahun. Peratus umur 18-25 tahun merupakan jumlah responden yang teramai iaitu sebanyak $46 \%$ manakala bagi responden yang berumur 26-35 tahun sebanyak 32\%. 22\% merupakan golongan responden yang berumur 36-45. Hal ini dapat dijelaskan bahawa golongan muda iaitu responden yang berumur diantara 18-25 tahun adalah responden yang banyak membeli secara atas talian.

\section{Carta 2 : Umur}
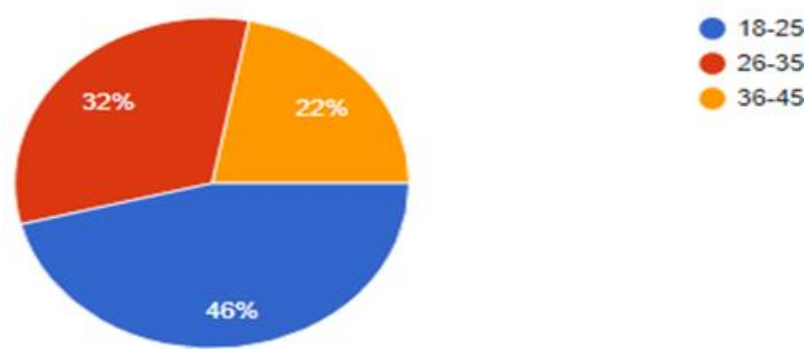

\section{Analisa Maklum Balas Pihak Perkhidmatan Kurier dan Pelanggan Semasa Pandemik Covid-19}

Bagi mengkaji cabaran terhadap pengeposan barang terhadap perkhidmatan kurier dan pengguna semasa pandemik Covid-19 ini, terdapat 13 soalan yang dibina yang perlu dijawab oleh responden bagi memudahkan kajian ini dijalankan. Carta 3 menunjukkan peratusan pengguna yang terkesan semasa pandemik Covid-19. Menurut soal selidik yang dijawab oleh responden, terdapat seramai $2 \%$ responden tidak terkesan, manakala seramai $98 \%$ responden menyatakan bahawa mereka terkesan dengan Pandemik Covid-19 ini. Hal ini kerana pengguna perlu duduk dirumah sepanjang pelaksanaan perintah kawalan pergerakan (PKP). 
Carta 3: Maklumat Terhadap Pengguna yang Terkesan

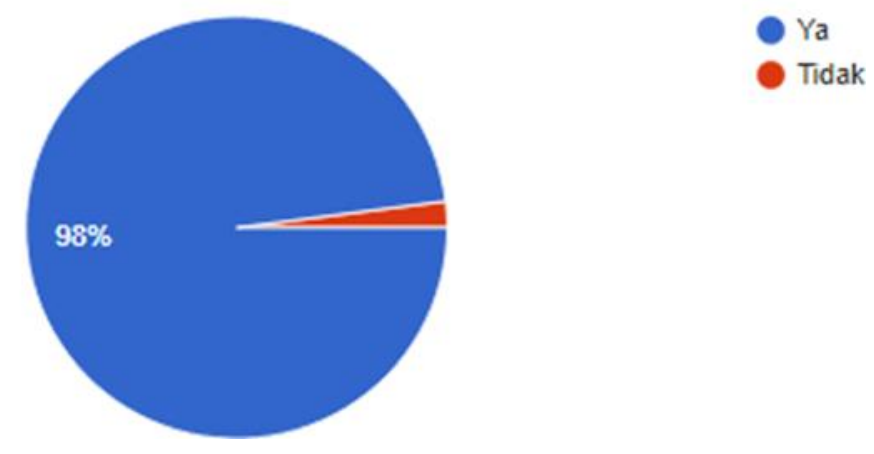

Carta 4 menunjukkan maklumat mengenai pembelian barangan responden semasa Pandemik Covid19. Seramai 50 orang responden iaitu peratusan sebanyak $100 \%$ responden membeli barangan. Kajian ini merungkai walaupun pada saat pandemik, responden tetap perlu untuk membeli barangan.

Carta 4: Maklumat Mengenai Pembelian Barangan

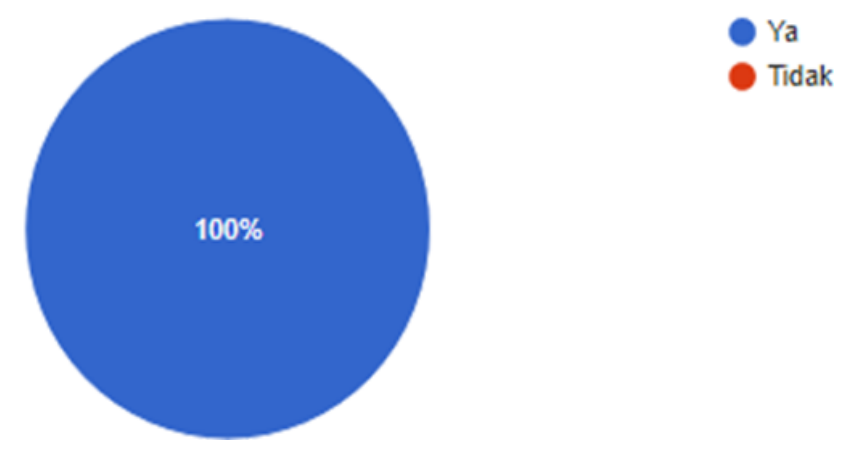

Carta 5 ini menunjukkan kajian terhadap barangan yang menjadi pilihan. Daripada 50 orang responden, 52\% responden memilih untuk membeli barangan keperluan. Manakala 28\% responden memilih barangan kehendak dan $20 \%$ memilih untuk membeli barangan yang menjadi kepuasan. Perbezaan dalam pemilihan barangan ini dipengaruhi oleh faktor jantina dan umur responden.

Carta 5: Maklumat Terhadap Pilihan Barangan

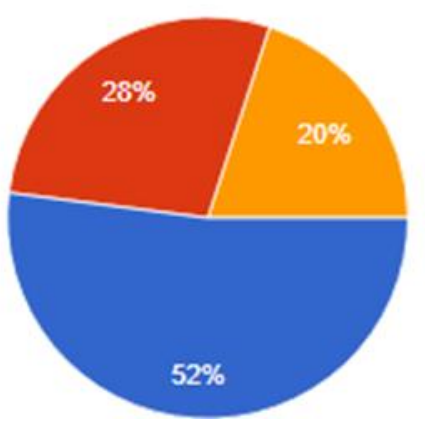

Barangan yang menjadi kepuasan 
Carta 6 ini menunjukkan sewaktu pandemik Covid-19, responden cenderung untuk membeli atas talian ataupun membeli di kedai. Menurut edaran borang soal selidik, terdapat seramai $80 \%$ responden untuk membeli secara atas talian berbanding hanya $20 \%$ responden memilih untuk membeli barangan secara terus dari kedai.

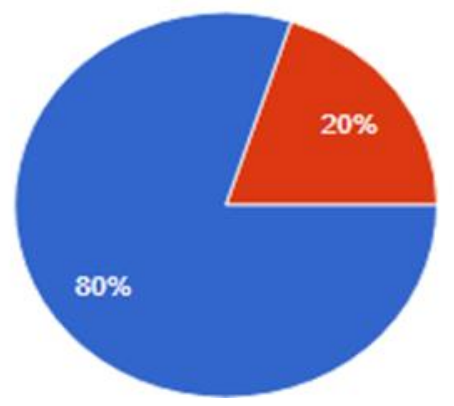

Atas talian

Kedai

Carta 7 menunjukkan terdapat 4 faktor dalam kecenderungan responden membeli secara atas talian sewaktu pandemik Covid-19. Antara faktornya adalah murah, cepat, berkualiti dan tidak perlu keluar rumah. 36\% responden menjawab bahawa mereka memilih membeli secara atas talian kerana barangan yang dipesan murah. Diikuti dengan 30\% responden memilih cepat sampai, manakala tidak perlu keluar rumah mendapat peratusan sebanyak $20 \%$. seramai $14 \%$ responden memilih kualiti sebagai kecenderungan mereka untuk membeli barangan secara atas talian.

\section{Carta 7: Maklumat Terhadap Kecenderungan Memilih Membeli Barangan}
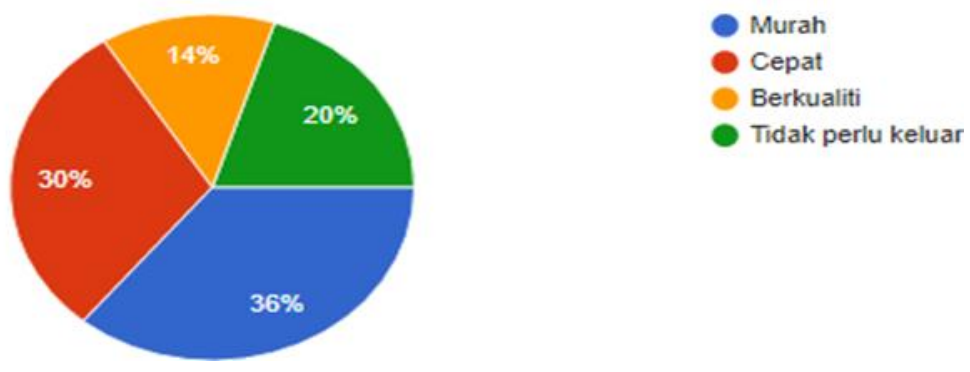

Carta 8 menunjukkan bahawa terdapat peratusan yang ketara terhadap pemilihan perkhidmatan yang sering digunakan dalam membeli barangan. Sebanyak $74 \%$ mempercayai perkhidmatan Pos Malaysia berbanding $26 \%$ responden memilih J\&T sebagai pilihan responden.

Carta 8: Maklumat Terhadap Perkhidmatan Yang Digunakan

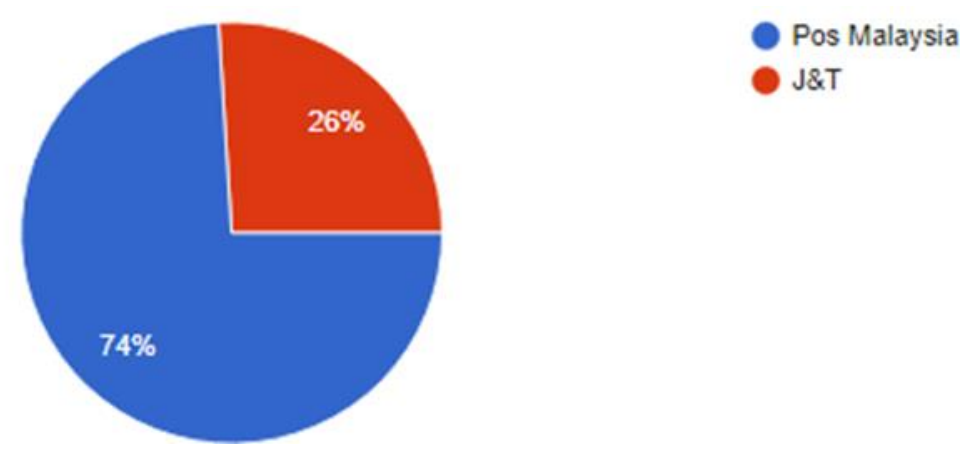

Carta 9 menunjukkan peratusan responden berpuas hati terhadap perkhidmatan penghantaran yang diberikan oleh Pos Malaysia. $82 \%$ responden berpuas hati dengan penghantaran yang dilakukan oleh Pos Malaysia manakala $18 \%$ responden tidak berpuas hati. 


\section{Carta 9: Maklumat Terhadap Kepuasan Yang Diterima}
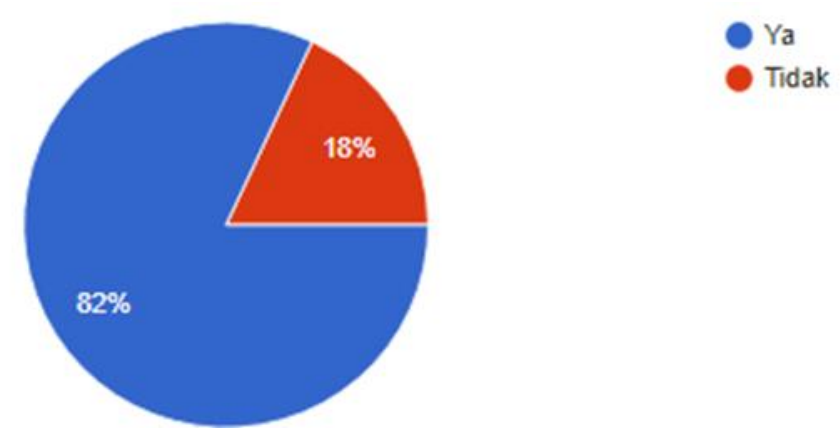

Dalam soalan selidik seterusnya, carta 10 menunjukkan bahawa anggaran waktu yang diterima responden terhadap pengeposan barangan yang dipesan. $18 \%$ daripada jumlah keseluruhan memilih barangan responden tidak sampai dalam waktu anggaran manakala $82 \%$ responden menyatakan bahawa barangan mereka sampai dalam anggara waktu yang ditetapkan. Hal ini kerana pengeposan barang mengikut kawasan tidak sama. Setiap halangan dan rintangan diambil kira dalam masa pengeposan sesuatu barangan.

Carta 10: Maklumat Terhadap Anggaran Waktu

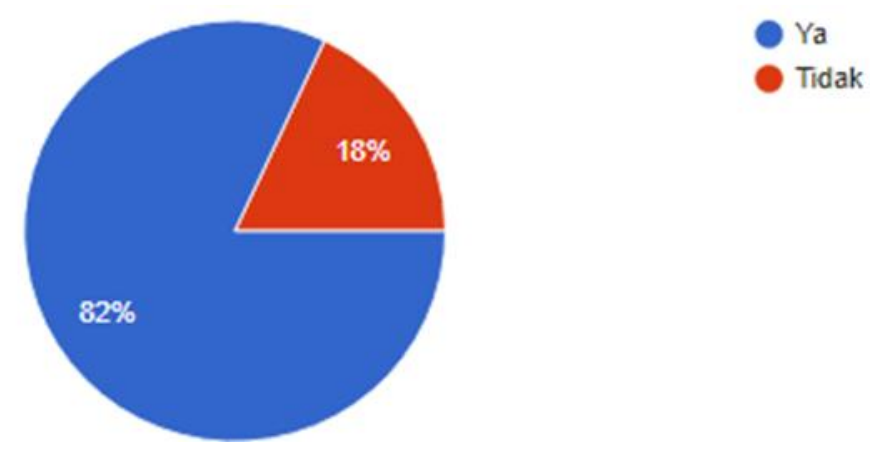

Carta 11 menunjukkan 52\% responden membeli barang 1-3 bilangan yang dipesan. Manakala 4-6 bilangan barangan sebanyak $40 \%$ dan selebihnya adalah 7-10 bilangan dan lain-lain adalah $8 \%$. Carta 12 ini menunjukkan mengenai kawasan yang didiami oleh responden. $62 \%$ responden tinggal di kawasan bandar. Dan selebihnya 38\% responden tinggal di kawasan luar bandar.

Carta 11: Maklumat Terhadap Bilangan barang yang dipesan
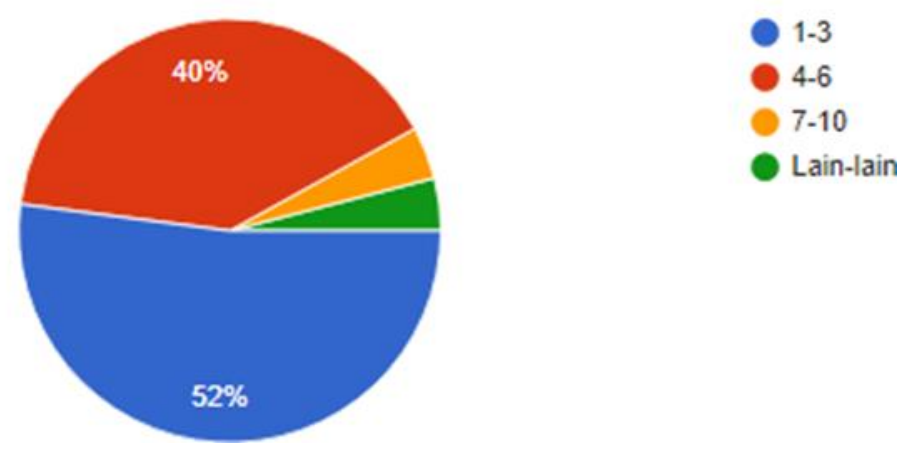
Carta 12: Maklumat Terhadap Kawasan Perumahan

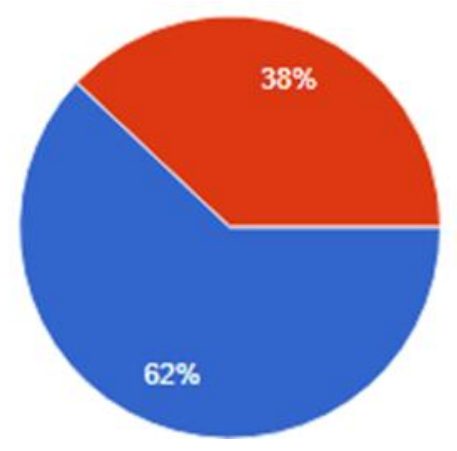

Bandar

Luar bandar

Carta 13 ini menunjukkan peratusan responden terhadap layanan yang diberikan semasa penghantaran barang. Kesemua responden iaitu $100 \%$ bersetuju bahawa layanan yang diberikan oleh Pos Malaysia adalah baik.

Carta 13: Maklumat Terhadap Layanan Yang Diberikan

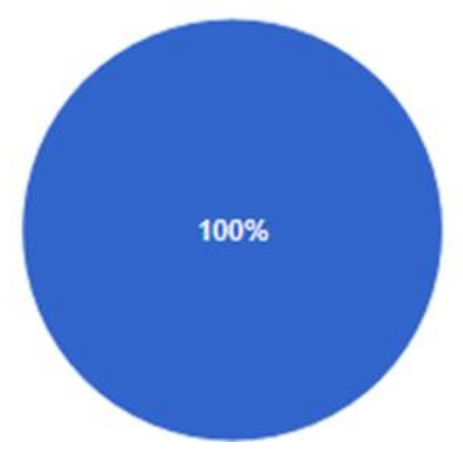

Baik

Sederhana

Kurang baik

Carta 14 ini menunjukkan maklumat mengenai kualiti barangan yang diterima kepada responden. Responden mengatakan bahawa kualiti barangan mereka $100 \%$ sampai dalam keadaan yang baik.

Carta 14: Maklumat Mengenai Kualiti Barangan

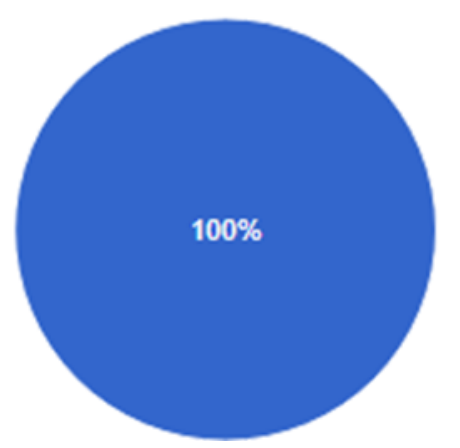

Ya

Tidak

Carta 15 menunjukkan maklumat yang diberikan oleh responden adakah mereka akan menggunakan lagi perkhidmatan pengeposan oleh Pos Malaysia. Peratusan responden menjawab 100\% mereka akan menggunakan perkhidmatan pengeposan dari Pos Malaysia. 


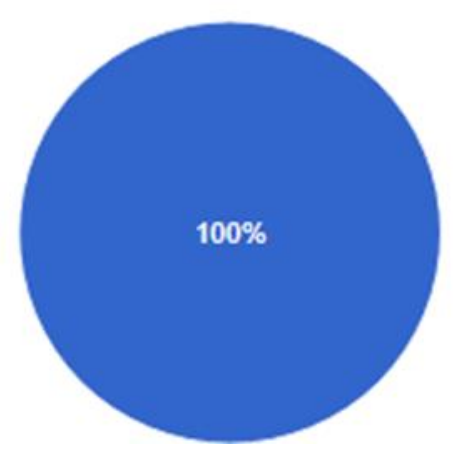

Ya

Tidak

\section{Perbincangan}

Objektif utama penyelidikan ini adalah untuk mengetahui peningkatan penggunaan perkhidmatan kurier semasa pandemik Covid-19 menyebabkan berlaku cabaran yang besar dalam perkhidmatan pengeposan barangan yang dilakukan oleh Pihak Pos Malaysia untuk melakukan kajian ini, 15 bilangan soalan telah diedarkan kepada pengguna secara atas talian melalui aplikasi Whatsapp dan mendapat seramai 50 orang responden iaitu 20 lelaki dan 30 perempuan yang telah menjawab soal selidik ini. Melalui cara ini, kajian dapat membuktikan bahawa kekerapan pembelian barangan secara atas talian menyebabkan penghantaran barangan lambat sampai kepada pengguna dan waktu anggaran yang ditetapkan melebihi waktu. Selain itu, kawasan penempatan pengguna juga menjadi penyebab kepada cabaran yang dialami oleh kurier-kurier di Malaysia.

Dari tinjauan literatur, cabaran yang dilalui oleh pihak perkhidmatan kurier dan pengguna adalah lambakan barangan di pusat perkhidmatan kurier yang akan menyebabkan kelewatan penghantaran barangan yang akan menimbulkan rasa tidak puas hati pengguna kepada perkhidmatan kurier tersebut. Kadar ketidakpuasan hati ini meningkat kepada $18 \%$ daripada responden yang telah menjawab soal selidik. Lambakan barangan bukan sahaja memberi kelewatan penghantaran tetapi juga berlaku kerosakan pada barangan yang dikirim. Hal ini memberi sedikit sebanyak kesan kepada pihak perkhidmatan kurier kerana ketidakpuasan hati pengguna yang menyebabkan pengguna beralih kepada syarikat perkhidmatan kurier yang lain. Selain itu, segmen kiriman bungkusan mendapat permintaan tinggi, disokong dengan lonjakkan pembelian dalam talian oleh rakyat Malaysia pada ketika arahan kerajaan supaya rakyat kekal dirumah. Walau bagaimanapun, pengguna akan terus menggunakan khidmat kurier Pos Malaysia ini bagi menghantar barangan yang dipesan secara atas talian. Kajian ini telah dibuktikan dengan data keseluruhan pengguna bersetuju untuk menggunakan perkhidmatan pengeposan ini dan mereka akan mula menyesuaikan diri dengan norma baru.

\section{Kesimpulan}

Wabak pandemik COVID-19 ini bukan sesuatu wabak penyakit berjangkit yang kita semua boleh meramalkan bila akan berakhir dan bagaimana keadaan pada masa hadapan. Sebagai pengguna yang bijaksana seharusnya mempunyai fikiran yang waras untuk membuat sesuatu tindakan dan juga pembelian. Pembelian barang secara berhemah dan menggunakan khidmat penghantaran yang dipercayai adalah yang perlu difikirkan. Hal ini kerana jika pengguna memudahkan kerja penghantaran yang dilakukan oleh pihak kurier terutamanya Pos Malaysia, barang yang dipesan oleh pengguna juga akan mudah dan selamat sampai. Seperti mana yang kita sedia maklum, syarikat perkhidmatan kurier bukan hanya menghantar barangan pengguna sahaja, malahan syarikat perkhidmatan kurier juga menghantar surat dalam masa yang sama ke seluruh Malaysia. Isu penghantaran barangan yang lambat dapat diselesaikan apabila kita sebagai pengguna dapat memberikan kerjasama yang baik dengan perkhidmatan kurier. Berikutan dari norma baru ini, pengguna akan menyedari bahawa barangan yang dibeli perlukan kesabaran yang tinggi untuk sampai kepada mereka dalam waktu yang telah ditetapkan. 


\section{Rujukan}

Ahmad. A. J. (2020, Mei). Transformasi Perkhidmatan Pos Malaysia Bermula Seiring Norma Baharu. Bahan diakses pada Mei 2020, daripada https://www.astroawani.com/beritamalaysia/transformasi-perkhidmatan-pos-malaysia-bermula-seiring-normal-baharu-243556

AmazingNara. (2020, April). Terlalu Ramai Beli Baranan Dalam Talian Semasa Pkp, Syarikat Kurier Lambt Hantar Bungkusan. Bahan diakses pada April 2020, daripada https://amazingnara.com/ terlalu-ramai-beli-barang-dalam-talian-semasa-pkp-syarikat-kurier-lambat-hantar-bungkusan/

Avid. (2020, April). Ini Sebab Barang Pos Laju Lambat Sampai Semasa PKP. Bahan diakses pada April 2020, daripada https://rencah.com/ini-sebab-barang-pos-laju-lambat sampai-semasa-pkp/

Bernama. (2020, 21 April). Sejauh Mana Khidmat Penghantaran Barang Selamat Bebas Covid-19. Bahan diakses pada 21 April 2020, daripada https://www.bernama.com/bm/am/news_covid19.php?id=1834157

Dones, R. L. E., \& Young, M. N. (2020, September). Demand on the of Courier Services during COVID-19 Pandemic in the Philippines. In 2020 7th International Conference on Frontiers of Industrial Engineering (ICFIE) (pp. 131-134). IEEE.

MyMetro. (2020, 23 April). Pos Laju Terima Sehingga 700,000 Parcel Sehari. Bahan diakses pada 23 April 2020, daripada https://www.hmetro.com.my/mutakhir/2020/04/570261/pos-laju-terimasehingga770000-parcel-sehari-metrotv

Ramalu. T. (2020, 28 Mei). Perkhimatan Kurier Talian Hayat Ketika PKPB. Bernama. Bahan diakses pada 28 Mei 2020, daripada https://www.bernama.com/bm/am/news_covid19.php?id=1845442

Ridho, F. (2019). Pengaruh Biaya Pengiriman Dan Waktu Pengiriman Terhadap Penghantaran Barang Pada Pt. Jne Cabang Medan . (Doctoral dissertation, Universitas Dharmawangasa).

Safbri. A. (2020, 9 April). Pos Malaysia Henti Hantar Parcel Ke Zon Merah. SinarHarian Online. Bahandiakses pada 9 April 2020, daripada https://www.sinarharian.com.my/article/78127/ KHAS/Covid-19/Pos-Malaysia-henti hantar-parcel-ke-zon-merah

Utusan Borneo Online. (2020, 15 Julai). Pos Malaysia: Peningkatan Bungkusan Mendadak Di Sabah dan Sarawak Cecah 1.39 Juta Pada Jun. Bahan diakses pada 15 Julai 2020, daripada https://www. utusanborneo.com.my/2020/07/15/pos-malaysia-peningkatanbungkusan-mendadak-di-sabah-dansarawak-cecah-139-juta-pada-jun

Zainuddin. M. Z. (2020, 6 Mei). Segmen Kurier Pos Malaysia Catat Permintaan Amat Tinggi. Berita Harian Online. Bahan diakses pada 6 Mei 2020, daripada https://www.bharian.com.my/ bisnes/korporat/2020/05/685759/pkp-segmen-kurier-pos-malaysia-catat-permintaan-amat-tinggi 